DEUÍFD Türk Kültürünü Mayalayanlar Özel Sayısı / 2021, ss. 491-510.

\title{
HACI BEKTAŞ VELÎ SONRASINDA BEKTAŞÎLİĞİN OLUŞUM VE GELIŞİMI*
}

Harun YILDIZ**

\section{ÖZ}

Hacı Bektaş Velî'den sonra dergâhında yetişen sûfiler, Balım Sultan'ın ortaya koyduğu yenilik ve düzenlemelerden dolayı iki ana zümreye ayrılmışlardır. Bu tarihsel ayrışmada Hacı Bektaş Velî’nin evlenip evlenmediği meselesi, önemli bir rol oynamaktadır. Hacı Bektaş Velî̀nin takipçilerinin bir kısmı, onun mücerret, yani bekar olarak vefat ettiğini; diğer bir kısmı ise, "Fatma Nuriye (Kadıncık Ana)" ile evlendiğini ileri sürerler. İlk görüşü benimseyenler, mücerret kol olan "Babagânlar/Babalar"; diğer görüşü benimseyenler ise, "Çelebiler" yani "Dedegânlar"dır. Bektaşî geleneği içerisinde Çelebiler, Hacı Bektaş Velî soyundan geldikleri düşüncesiyle "bel evlâdı"; Babagânlar ise, onun soyundan gelmeyip Hacı Bektaş Velî’nin yol ve ilkelerini takip etmeye verdikleri önem nedeniyle "yol evlâdı" olarak adlandırılırlar. Bu ayrım, mücerretlik erkânının uygulanmaya başlamasıyla birlikte daha da netleșmiştir. Bu noktada bu bildiride bu tartışmalar ekseninde Hacı Bektaş Velî sonrasında Bektaşilliğin teșekkül ve gelişimi ortaya konulmaya çalışılacaktır. Bu çerçevede öncelikle, Hacı Bektaş Velî’nin arkasından tarikatın ikinci pîri olarak kabul edilen Balım Sultan’a kadar geçen süreç üzerinde durulacaktır. Arkasından, Balım Sultan ve dönemi ile Balım Sultan'dan günümüze yaşanan gelişmeler ana hatlarıyla ele alınacaktır.

Anahtar Kelimeler: Hacı Bektaş Velî, Balım Sultan, Çelebiler, Babagânlar.

* Yazar; çalışmanın hazırlanması esnasında bilimsel ve etik ilkelere uyulduğunu ve yararlanılan tüm kaynakların kaynakçada belirtildiğini, çalışmanın maddi açıdan fonlanmadığını, çıkar çatışması bulunmadığını beyan etmektedir.

Bu makale, Tarihi, Dini, Sosyal ve Güncel Boyutlaryla Alevîlik Bektaşîlik (Bilay Yay., Ank., 2021) isimli çalışmamızın ilgili kısmının yeniden gözden geçirilerek geliştirilmiş olan şeklidir.

** Prof. Dr., Ondokuz Mayıs Üniversitesi, İlahiyat Fakültesi, Samsun, Türkiye, Ondokuz Mayis University, Faculty of Theology, Samsun, Turkey, hyildiz@omu.edu.tr; ORCID ID: https://orcid.org//0000-0002-8524-0593.

Makalenin Hakemlere Gönderiliş Tarihi : 06/12/2021

Makalenin Hakemlerden Geliş Tarihi : 20/12/2021 


\section{THE FORMATION AND DEVELOPMENT OF BEKTASHISM AFTER HAJI BEKTASH VELI}

\section{ABSTRACT}

The Sufis who grew up in the Haji Bektash Veli Lodge were divided into two main groups after him due to the innovations and regulations put forward by Balim Sultan. In this historical disintegration, the issue of whether he married or not has an important place. Some of Haji Bektash Veli's followers claim that he died as a mujarrad, that is, a single. On the other hand, the others claim that he married "Fatma Nuriye (Kadincik Ana)". Those who accept the first view are the "Babagans/Fathers" which is the mujarrad branch. Those who accept the other view are the "Çelebis", that is, the "Dedegans". In the Bektashi tradition, the Çelebis are called "waist boy", because they are descended from Haji Bektash Veli. Babagans, on the other hand, are not descended from him, but they are called "the children of the road", because they care about following the way and principles of Haji Bektash Veli. In this paper, on the basis of these discussions, the formation and development of Bektashism after Haji Bektash Veli will be tried to be revealed. In this framework, first of all, the process from Haji Bektash Veli to Balim Sultan, who is accepted as the second period of the order, will be emphasized. Afterwards, Balim Sultan and his period and the developments from Balim Sultan to the present will be discussed in outline.

Keywords: Haji Bektash Veli, Balim Sultan, Çelebis, Babagans.

\section{GİRİ̧}

Hacı Bektaş Velî, kuşkusuz yaşadığ1 ortamda yeni bir öğreti inşa etmeye çalışmış olup onun bu çerçevede bazı kuramsal esaslar ortaya koyduğunu söylemek mümkündür. Ancak bu durum, onun yaşadığ1 dönemde kendi adına kurumsallaşmış bir tarikat inşa ettiği anlamına gelmemektedir. Zira Bektaşilik, bir tarikat olarak ona nispetle daha sonra kurulmuş ve kurumsal bir kimlik kazanmıştır. Bu bağlamda Hacı Bektaş Velî̀nin Cemal Seyyid, Hacım Sultan ve Abdal Musa gibi öğrencilerinin Bektaşiliğin tarihsel anlamda gelişimi ile teşekkül sürecindeki önemli yerleri göz ardı edilmemelidir. Çünkü Bektaşîliğin hem Anadolu coğrafyasında, hem de Anadolu dışında Balkanlar ve Mısır gibi bölgelerde yayılmasında öğrencilerinin ciddi bir rolü vardır.

Hacı Bektaş Velî sonrasında bu dergâhta yetişen sûfiler, daha çok Balım Sultan'ın ortaya koyduğu yenilik ve düzenlemelerden dolayı iki ana 
zümreye ayrılmışlardır. Bu tarihsel ayrışmada Hacı Bektaş Velı̀nin evlenip evlenmediği meselesi, önemli bir rol oynamaktadır. Bu yüzden Hacı Bektaş Velînnin takipçilerinin bir kısmı, onun mücerret, yani bekar olarak vefat ettiğini ileri sürerken; diğer bir kısmı ise, "Fatma Nuriye (Kadıncık Ana)" ile evlendiğini ve ondan çocukları olduğunu ileri sürerler. İlk görüşü benimseyen zümre, Hacı Bektaş Velî’nin mücerret olarak yaşadığını ileri süren "Babagânlar/Babalar"; diğer görüşü benimseyenler ise, "Celebiler" yani "Dedegânlar”dır. Bektaşî geleneği içerisinde Çelebiler, Hacı Bektaş Velî soyundan geldikleri düşüncesiyle "bel evlâdı"; Babagânlar ise, onun soyundan gelmeyip Hacı Bektaş Velî’nin yol ve ilkelerini takip etmeye verdikleri önem nedeniyle "yol evlâdı" olarak adlandırılırlar. Bu bağlamda Babagânlar kolu, Hacı Bektaş Velî’nin mücerret kaldığına, yani hiç evlenmediğine inanmaktadır. Onlara göre Hacı Bektaş Velî, bekar olarak yaşamış ve bu şekilde bu dünyadan göçmüş/ayrılmıştır. Bu yüzden Kadıncık Ana, onun eşi değil mürididir. Kadıncık Ana evlâdı ise, Hacı Bektaş Velî’nin burun kanından gelme manevi evladı olup "bel evlâdı" değil, "nefes evlâdi"dır. Bu ayrım, mücerretlik erkânının uygulanmaya başlamasıyla daha net biçimde ortaya çıkmıştır. ${ }^{1}$

Çelebiler, Hacı Bektaş Velî̀nin Sulucakarahöyük'te yerleşmesinin arkasından, zaman içerisinde İdris Hoca'nın kızı Fatma Nuriye (Kadıncık Ana) ile evlenerek bu evlilikten İbrahim Seydi (Seyyid Ali Sultan/Timurtaş) adı verilen bir çocuğunun dünyaya geldiğini ve Hac1 Bektaş Velî'den sonra onun posta oturduğunu ifade ederler. Çelebiler'e göre asıl ismi Fatma Nuriye olan Kadıncık Ana, İdris Hoca ile Kutlu

\footnotetext{
Bektaşiliğin Babagân kolu, görüşlerini Vilâyet-nâme'de anlatılan ilginç bir olaya dayandırmaktadır. Buna göre Hacı Bektaş Velî, bir gün abdest alırken burnu kanar ve Kadıncık Ana'dan bu abdest suyunu ayak değmeyecek tenha bir yere dökmesini ister. Bunun üzerine Kadıncık Ana, bu suyu o görmeden içer ve böylece çocukları olur. Bu rivayete göre Hacı Bektaş Velî, yeni doğan çocuklara Habip ve Hızır Lale adını koyar ve bunlar, Hacı Bektaş Velî’nin ölümünden sonra vasiyeti üzere onun yerine geçerler. Bkz., Abdülbâki Gölpınarlı, Vilâyet-nâme Menâkıı-ı Hünkâr Hacı Bektâş-ı Velì, (İstanbul: İnkilap Kitabevi, 1995), s. 63-64; A. Celalettin Ulusoy, Hünkâr Hacı Bektaş Velì ve Alevî-Bektaş̧̂ิ Yolu, (Hacibektaş, 1986), s. 33-34; ayrica Hacı Bektaş Velî’nin nefes evlâdları için bkz., Suraiya Faroqhi, "XVI-XVIII. Yüzylllarda Orta Anadolu'da Şeyh Aileleri”, Yol Dergisi, 22, (2003), s. 80-81.
} 
Melek'in kızı olup daha sonra Hacı Bektaş Velî ile evlenmiştir. ${ }^{2}$ Bu noktada ifade etmemiz gerekir ki bazı araştırmacılara göre Çelebiler, Türk Bektaşiliği; Babagân kolu ise, Rumeli ve Amavutluk Bektaşiliği olarak nitelendirilir. ${ }^{3} \mathrm{Bu}$ tartışma, aslında sıradan bir tartışma olmayıp Bektaşiliğin daha çok hangi yol ve kanaldan devam ettiğini göstermeye çalışan iki tarafın varlıklarını ortaya koyma mücadelesi gibi görünmektedir.

Bektaşiliğin tarihsel gelişimini belli dönemler halinde ele almak mümkündür; Bu noktada ilk dönem, bilindiği gibi Hacı Bektaş Velî̀nin Sulucakarahöyük'e yerleşmesinden başlayarak Balım Sultan'ın (922/1516) post-nişîn olmasına kadar geçen devre olan XIII. yüzyıl ortalarından XVI. yüzyılın başlarına kadar geçen dönemdir. Ardından Balım Sultan'ın post-nişîn olmasindan Bektaşiliğin lağvedildiği döneme kadar geçen süreç (1501-1826), Bektaşîliğin gelişiminde ikinci devre olarak adlandırılabilir. Daha sonraki önemli dönemler ise, Bektaşiliğin lağvedilmesinden itibaren Cumhuriyet döneminde tekkelerin kapatılmasına kadar geçen dönem (1826-1925) ve tekke ve zaviyelerin kapatılmasından Hacı Bektaş Velî Külliyesi’nin müzeye dönüştürülmesine kadar geçen dönem (1925-1964) ile son olarak bu tarihten günümüze yaşanan süreç şeklinde ifade edilebilir. Bu şekilde Bektaşîliğin tarihsel gelişimi, beş ana dönem halinde incelenebilir.

Bu bildiride bu tartışmalar ekseninde Hacı Bektaş Velî sonrasında Bektaşilliğin teşekkül ve gelişimi ortaya konulmaya çalışılacaktır. Bu çerçevede öncelikle, Hacı Bektaş Velî̀nin arkasından tarikatın ikinci pîri olarak kabul edilen Balım Sultan'a kadar geçen süreç üzerinde durulacaktır. Arkasından, Balım Sultan ve dönemi ile Balım Sultan'dan günümüze yaşanan gelişmeler ana hatlarıyla ele alınacaktır.

\section{Hacı Bektaş Velî’den Balım Sultan'a Kadar Geçen Süreç}

Hacı Bektaş Velî, vefatından önce şekillendirmeye çalıştığ dinî hareketin temel ilkelerini ortaya koyarak yeni bir öğreti inşa etmeye

\footnotetext{
2 E. Ruhi Fığlalı, Türkiye'de Alevîlik Bektâsîlilik, (İzmir; İzmir İlahiyat Vakf1 Yay., 2006), s. 126, 156-158; Ulusoy, 29-30, 67; Ali Yaman, Alevilik \& Kı̨llbaşlik Taribi, (İstanbul: Nokta Kitap, 2007), s. 108-109.

3 Yaman, 79.
} 
çalışmıştı. Ancak kendi döneminde bu öğreti, henüz kurumsallaşma imkanına kavuşmamıştı. Yani Hacı Bektaş Velî, yaşadığı sürece Bektaşîlik şeklinde bir tarikat oluşmuş değildir. ${ }^{4} \mathrm{Bu}$ dönemde tarikat şeklinde kurumsallaşmış bir yapılanma gerçekleşmese bile, Hacı Bektaş Velî’nin düşünce ve mesajlarına önem veren çevrelerin bir araya gelmesi ile bu yapının ilk tezahürlerinin ortaya çıkmaya ve şekillenmeye başladı̆̆ı görülmektedir. Zira Hacı Bektaş Velî̀den sonraki süreçte öğrencileri, hem Hacıbektaş'ta onun dergâhı etrafinda, hem de gittikleri değişik coğrafyalarda halk kitlelerine onu anlatmak suretiyle onun fikir ve ögretileri ile manevi mirasını daha da geliştirmişlerdir.

Aslında Hacı Bektaş Velî̀nin öğrencileri, Bektaşilliğin tarihsel olarak gelişimi ile teşekkül sürecinde önemli yeri olan sûfîlerdir. Hacı Bektaş Velî sonrasında Bektaşî çevreler, önemli gelişmeler göstererek günümüze gelmişlerdir. Hac1 Bektaş Velî̀den sonraki ilk yöneliş ve oluşum süreci, XIII ve XIV. yüzyıllarda önemli bir tasavvufî düşünce akımı olan Kalenderilik içerisinde gerçekleşmiş olup Bektaşilik, daha sonra XV. yüzyılda Hacı Bektaş Velî’nin an'aneleri etrafında ortaya çıkarak kurumsallaşmış ve sonraki yıllarda Osmanlı toplum yaşamının hemen her alanında büyük bir nüfuz ve etkiye sahip olmuştur. Bu anlamda Hac1 Bektaş Velî̀nin öncülük ettiği inanç, ideal ve değerler ile tarihsel süreç içerisinde kurumsal hale gelen erkân ve ritüelleri, bir öğreti ve paradigma olarak benimseyen geniş bir kitle, her zaman var olmuştur. Bu noktada önemli aşamalardan geçen Bektaşî topluluklar, farklı süreçlerden geçerek günümüzdeki yapıya kavuşmuşlardır.

Bektaşilliğin Hacı Bektaş Velî sonrasındaki gelişim sürecinde öğrencilerinin oldukça önemli bir yeri vardır. Hacı Bektaş Velî̀nin öğrencileri arasında Cemal Seyyid, Koluaçık Hacım Sultan, Sarı İsmail, Güvenç Abdal, Barak Baba, Rasul Baba, Huy Ata, Karadonlu Can Baba, Taptuk Emre, Hızır Samit, İbrahim Hacı, Pir Ebî (Pîrâb Sultan) Sultan ve Koçum Seydî, en seçkin olanlarıydı. ${ }^{5}$ Yine vilâyet-nâme'nin verdiği bilgilere bakıldığında, öğrencilerinin içinde özellikle üç tanesinin

4 Cengiz Gündoğdu, Hacı Bektâs-ı Velì Öğretisi ve Takipçileri Hakkında Metodik Yeni Bir Yaklaşım, (Ankara: Aktif Yay., 2007), s. 206.

5 Gölpınarlı, 38-47, 76-78; M. Fuad Köprülü, "Bektaş”, İslam Ansiklopedisi, (İstanbul: Milli Eğitim Bakanlığ1 Yay., 1979), 2/461. 
diğerlerine göre ön planda olması dikkat çekicidir. Bunlar, Cemal Seyyid, Kolu açk. Hactm Sultan ve Sar İsmail dir.

Hacı Bektaş Velî’nin öğrencileri, Anadolu'nun siyasal ve askeri hareketliliğin yoğun olduğu uç bölgelerine giderek Hac1 Bektaş düşüncesinin Batı Anadolu'ya ve hatta Balkanlar'a doğru yayılmasını sağlamışlardır. ${ }^{6}$ İlk Bektaşîler, yaşadıkları bölgelerde kurmuş oldukları zaviyelerde hem insanları eğitme ve aydınlatma faaliyetlerinde bulunarak Hacı Bektaş Velî düşüncesini yaymış, bu şekilde İslamlaşma sürecine ciddi anlamda katkı sağlamışlar; hem de yaşadıkları bölgelerdeki Türkmenlerin konar-göçerlikten yerleşik toplumlar haline ve yerleşik hayata geçmeleri gibi önemli bir sosyal değişimin gerçekleşmesi için büyük çaba sarf etmişlerdir.'

\section{Balım Sultan ve Bektaşîliğin Kurumsallaşması}

Hacı Bektaş Velî sonrasında Bektaşîliğin gelişiminde esas önemli devreyi, Balım Sultan (922/1516) dönemi oluşturur. Zira Bektaşîliğin günümüzdeki yapısını kazanması, önemli ölçüde tarikat içerisinde Pîr-i Sânı̂ (ikinci pîr) olarak kabul edilen Balım Sultan ile başlayan süreçte gerçekleşmiştir. Bektaşî gelenek içerisinde oldukça önemli bir şahsiyet olarak kabul gören Seyyid Ali Sultan'ın torunu olan Balım Sultan ile birlikte Bektaşiliğin tarihsel gelişiminde artık ikinci önemli dönem başlamaktadır.

Hayatı hakkında çok fazla şey bilinmeyen Balım Sultan'ın asıl ismi, Hızır Bali olup, bilindiği gibi, Osmanlı sultanı II. Bayezid’in isteği üzerine 1501 y1lında Dimetoka'da bulunan Seyyid Ali Sultan dergâhından gelerek Hacıbektaş'taki dergâhın başına geçmiştir. Esasında Osmanlı

6 Bektaşiliğin coğrafi anlamda gelişimi ve Bektaşî tekkelerinin coğrafi dağılımı için bkz., Faroqhi, Anadolu'da Bektaşilik, Çev. Nasuh Barın, (İstanbul: Simurg Yay., 2003), s. 47-86, 191-193.

7 Hacı Bektaş Velî ile ilgili vilâyet-nâme'de geçen, kendisine doğru hayvanlar üzerinde gelen dervişleri, duvarı yürütmek suretiyle karşıladığını ifade eden menkıbe (Gölpınarlı, 1995: 49) ile ilgili olarak Hacı Bektaş Velî̀yi, bu çerçevede göçebe ve konar-göçer Türkmen çevrelerini yerleşik kültür ile yerleşik hayata geçişe hazırlayan ve bu sosyal değişime yönlendiren önemli bir düşünür olarak değerlendirmek mümkündür. Bu noktada ayrıca Bektaşî tekke ve zaviyelerinin sosyal ve ekonomik faaliyetleri için bkz., Faroqhi, Anadolu'da Bektaşilik, s. 87-156, 193-195. 
siyasal iktidarı, bu kararla birlikte oldukça önemli bir adım atmıştı. Zira bununla hem Bektaşî çevreleri kontrol altına almayı, hem de Anadolu'daki kızılbaş çevreleri, Safevî yayılmacıllğının etkilerinden korumayı hedefliyordu.

Balım Sultan, tarikat içinde âyin ve erkân bakımından bazı düzenleme ve yenilikler ortaya koymuş, örnek olarak Bektaşî cemlerindeki on iki post erkânı ile on iki hizmet geleneğini başlatmış, tarikat içinde mücerredlik denilen evlenmeme kuralını getirerek yeni bir mücerred (hiç evlenmeyen) dervişler zümresi meydana getirmiş ve mücerred dervişlerin kulaklarına küpe (mengüş) takma ritüelini başlatmıştır. Ayrıca Bektaşî tekkelerini yeniden yapılandırarak merkez tekkenin diğer tekkeler üzerindeki kontrolünü daha da artırmıştır. Bu çerçevede bir yandan tekkelerin iç teşkilatını daha sıkı ve muntazam bir hale getirirken, öte yandan çok sayıda tekkeden oluşan geniş bir tekke ağının ortaya çıkmasını ve böylece Bektaşiliğin geniş kitlelere ulaşmasını sağlamıştır. Öyle ki bu süreçte her 30 kilometre mesafede bir Bektaşî tekkesi kurulmuştur. ${ }^{8}$

Balım Sultan'la birlikte Bektaşîlik, devlet nezdinde ilgi ve himaye görerek artık daha fazla güçlenme imkanını bulmuştur. Bu yüzden Bektaşîlik, bu yeni süreçte Osmanlı Devleti'nin himayesinde özellikle şehir merkezlerinde önemli tekkelerde örgütlenmiştir. Bektaşilik, artık Anadolu'nun dişına daha fazla çıkarak Balkanlar'da Arnavutluk, Bulgaristan ve Romanya gibi daha geniş bir coğrafyada yayılmış, yine Misır, Suriye, Irak, Ege ve Akdeniz adaları, hatta İran ve Azerbaycan gibi ülkelerde de yayılarak taraftar bulma imkanına sahip olmuştur. Bektaşiliğin Balkan coğrafyasına yayılmasında Seyyid Ali Sultan (Kızıldeli), Otman Baba, Demir Baba ve Akyazılı Sultan gibi Hacı Bektaş takipçilerinin önemli bir etkisi vardır. ${ }^{9}$

Fığlalı, 162-169; Bedri Noyan, Bütün Yönleriyle Bektâş̧îlik ve Alevîlike, (Ankara: Ardıç Yay. 1998), I, 305-311; Rıza Yıldırım, Hacı Bektass Veli'den Balım Sultan'a Bektasiliğin Doğusu, (İstanbul: İletişim Yay., 2019), s. 261-275.

9 Bkz., Hakk1 Sayg1, Türklerin Balkanlara Geçişi ve Alevi-Bektaşi Zümreler, (İstanbul: Cem Vakfi Yay., 2013), s. 74-228; Refik Engin, Trakya ve Balkanlarda Bektaşillik ve Bektaşî Sürekleri, (Malberg Almanya: Alevi-Bektaşi Kültür Enstitüsü Yay., 2014), s. 36-48; Murat Küçük, Bir Nefes Balkan Taribten Günümüze Makedonya ve Arnavutluk'ta Bektaşilik, (İstanbul: Horasan Yay., 2006), s. 11-29; Harun Yıldız, "Balkan 
Bektaşî geleneğinde bilinen ilk yazılı erkânnâme de, Balım Sultan Erkannâmesi adıyla tanınmış olup bu erkânnâmenin orijinal ismi, Erkânnâme-i Bektâssiyân ve Kavânîn-i Yeniçeriyân'dır. ${ }^{10}$ Esasında Bektaşiliğin bir nevi iç tüzüğü olan Bektaşî erkannâmelerinin ilk örneğini Kaygusuz Abdal yazmış olup Balım Sultan'ın bu erkannâmeyi geliştirerek kurumsallaştırdığ1 anlaşılmaktadır. ${ }^{11} \mathrm{Bu}$ noktada özellikle mücerredlik erkânının uygulanmaya başlanmasından sonra Bektaşilliğin merkezi otoritesi, Babagânlar ve Celebiler/Dedegânlar olmak üzere ikiye ayrılmış ve bu ayrım, şiddetli bir rekabetle günümüze kadar devam etmiştir. ${ }^{12} \mathrm{Bu}$ yeni âdâb ve erkândan dolayı olsa gerek, özellikle Balkanlar'da yaşayan AlevîBektaşî çevreler arasında, Balım Sultan Erkâmı deyimi artık yaygınlaşmıştır. Balım Sultan'ın 1501 ile 1516 yılları arasında yapmış olduğu bu düzenlemeler, Bektaşiliğin artık gelişim ve kurumsallaşmasını sağlamıştır.

$\mathrm{Bu}$ yeni dönemde Balım Sultan'ın ortaya koyduğu yeni yapılanmayla birlikte, Hacıbektaş'taki Pir Evi'ne Çelebilerin başkanlık etmeleri geleneği de, sona ermiş olup artık tekkeyi babalar, yönetmeye başlamışlardır. $\mathrm{Bu}$ süreçte Çelebiler, geri planda kalarak tekke gelirlerinden az da olsa paylarını almakla birlikte daha çok kendilerine bağlı olan ocakzâde dede ve babaların meseleleri ile meşgul olarak varlıklarını sürdürmüşlerdir. ${ }^{13}$ Bektaşî çevrelerdeki bu gelişmeler, öyle kolay gerçekleşen hadiseler olmayıp bir hayli çalkantılı ve sancılı bir sürecin sonunda meydana gelmiş ve sonuçları yüzyıllar boyunca onları etkilemiştir. Bu noktada Bektaşî teriminin de ilk defa ve müstakil bir

Coğrafyasında Alevîlik-Bektaşillik: Farklı Ocak ve Sürekler”, Uluslararası Geçmişten Geleceğe Alevilik Sempozyumu, (Ankara: Alevî İnanç Birliği Vakfi, 2018), s. 327-329.

10 Bu erkânnâmenin günümüzde üç yazma nüshası tespit edilmiş olup bunlardan biri, Bedri Noyan Dedebaba'da, ikincisi Turgut Koca Halifebaba'da, üçüncüsü ise, Vatikan kütüphanesindedir. Bkz., Şevki Koca, Bektâş̧îlik ve Bektâş̧̂̀ Dergâblar, (İstanbul: Cem Vakf1 Yay., 2005), s. 21.

11 Fahri Maden, Hacı Bektaş-ı Veli, (İstanbul: Erdem Yay., 2019), s. 92.

12 Fiğlalı, 164-166; Yıldırım, Bektaşiliğin Doğuşu, s. 295-304; 315-320; Gündoğdu, 254255; ayrıca Çelebiler için bkz., Meral Salman Yıkmış, Hacı Bektaş Veli'nin Evlatlar "Yol"un Mürşitleri: Ulusoy Ailesi, (İstanbul: İletişim Yay., 2014), s. 49-76; Yıldırım, Bektasiliğ̈in Doğusu, s. 243-259.

13 Yaman, 110-111. 
zümrenin adı olarak, XVI. yüzyıl başlarından itibaren kullanılmaya başlandığ1 söylenebilir. ${ }^{14}$

Bektaşî geleneği, bu süreçte Hacı Bektaş Velî̀nin yukarıda ifade ettiğimiz öğrencilerinin içinde olmayan fakat Hacı Bektaş Velî ile aynı y1llarda ya da daha sonraki dönemlerde yaşamış olan Karaca Ahmed Sultan, Sarı Saltık, Geyikli Baba, Sultan Şücâeddin, Abdal Musa ve Akça Koca gibi bazı Kalenderî/Vefâî ve Melâmî dervişlerini Hacı Bektaş Velî̀nin öğrencisi imiş gibi kabul ederek böyle algılamıştır. ${ }^{15} \mathrm{Bu}$ durum, Hac1 Bektaş Velî'den sonra IX/XV. yüzyıllarda Bektaşîliğin teşekkül etmeye başlayarak tarihsel anlamda gelişimiyle yakından ilişkilidir. $\mathrm{Bu}$ süreçte artık Hacı Bektaş Velî’nin halk arasında bilinen menkıbeleri yayılarak menkıbevî bir Hacı Bektaş kültü oluşmaya başlamış ve bu durum, onun asıl tarihsel kimliğinin gölgede kalarak unutulmasına yol açmıştır. Yine süreç içerinde Hacı Bektaş Velî kültünü merkeze alan Bektaşî geleneği, Vefâiler, Haydarîler, Abdallar, Işılarar, Ahiler ve Kalenderîler gibi gayr-i sünnî olarak görülebilecek tasavvufî akım ve tarikatlarla kucaklaşarak onları kendi bünyesi içine almış; ardından bir tarikat olarak kurumsallaşma aşamalarını tamamlayıp söz konusu tasavvufî akım ve grupları, Bektaşîlik şemsiyesi altında bir araya

14 A. Yaşar Ocak, Osmanli Imparatorluğu'nda Marjinal Sûfîlik: Kalenderîler, (Ankara: Türk Tarih Kurumu Yay., 1999), s. 207.

15 Bu dervişlerin içinde, hakkında birçok rivayetin yer aldığı Sar Saltık (697/1297-98) ile ilgili bilgiler, tıpkı diğerleri gibi, biraz problemli görünmektedir. Zira Ocak’a göre Vilâyet-nâme-i Hacı Bektaş, Vilâyet-nâme-i Otman Baba ve Evliya Çelebi Seyahatnamesi gibi eserlerdeki menkıbeler, Sarı Saltık'1 Hacı Bektaş'ın halifesi ve müridi olarak takdim ederken; bunlarla aşağ1 yukarı aynı dönemde yazılmış olan Saltıknâme ise, her ikisi arasında böyle bir ilişkinin bulunduğundan söz etmemektedir. $\mathrm{Bu}$ durum, Sarı Saltık'in Bektaşîliğin teşekkül sürecini tamamlamasından sonra, Bektaşî panteonu içerisine sokulmuş olabileceğini göstermektedir. Bkz., Ocak, Sarr Saltık Popüler İslâm'ın Balkanlar'daki Destanî Öncüsü, (Ankara: Türk Tarih Kurumu Yay., 2002), s. 120-121; İbn es-Serrâc, Tuffâbu'l-Ervâh ve Miftâhu'l-Irbâh, Haz. Nejdet Gürkan, M. Necmettin Bardakçı, M. Saffet Sarıkaya, (İstanbul: Kitap Yay., 2015), s. 64-69, 319-327; Köprülü, “Anadolu Selçuklular1 Tarihi'nin Yerli Kaynaklar1”, Belleten, VII/25, (1943), s. 430-440; Machiel Kiel, "Sar1 Saltuk", Türkiye Diyanet Vakefi İlâm Ansiklopedisi, (İstanbul: Türkiye Diyanet Vakfı Yay., 2009), 36/147-150. 
getirmiştir. ${ }^{16}$ Öyle ki yine bu yüzden olsa gerek, Hacı Bektaş Velî’nin türbesi, Hıristiyanlar tarafindan bile ziyaret edile gelmiş; hatta bu şekilde bazı türbeler, çift yönlü/iki taraflı Bektaşî-H1ristiyan dergâhları olarak kabul edilmiştir. ${ }^{17}$

Balım Sultan'ın getirmiş olduğu yenilikler ve yapısal değişikliklerle Bektaşilik, Anadolu'da pek çok yerde yayılmakla kalmamış, benzer şekilde Balkan coğrafyasında da hızlı biçimde yayılmaya başlamıştır. Bu yeni dönemde artık Yeniçeri ocağı, önemli ölçüde Bektaşiliğe bağlanmıştır. ${ }^{18}$ Yeniçerilerin Hac1 Bektaş’a bağlanması ile Hac1 Bektaş Tekkesi, Anadolu'da artık merkez bir tekke durumuna gelmiştir. Yine Faroqhi'nin ifadesiyle, yeniçerilerle Bektaşîler arasındaki bu ilişki, her ne kadar resmi belgelerde hayret edilebilecek kadar az akis bulsa da ${ }^{19}$, Bektaşilik, artık bir tarikat olarak devlet nezdinde ilgi ve himaye görmeye başlamış, bu şekilde daha fazla güçlenme imkanı bulmuştur. Bu yeni süreçte Bektaşîler, devlet desteğinin vermiş olduğu güç ve imkanlarla özellikle şehir merkezlerinde ve önemli tekkelerde örgütlenmişlerdir.

16 XVII. yüzyıl Osmanlı müelliflerinden olan Karakaşzâde Ömer Efendi (1047/1637) de, bu gelişmeye dolaylı olarak temas etmektedir. Bkz., Karakaşzâde Ömer Efendi, Nûru'l-Hüdâ Limen İhtedâ, (Dersaâdet: Tasvîr-i Efkâr Mat., 1286), s. 5-6.

17 Hiristiyanlar, burada vaktiyle Ayios/Aziz Haralambos isimli bir Hıristiyan manastırı olduğunu da iddia etmektedirler. Bu yüzden türbeye girerken haç çıkarırlar. Bkz., Frederick W. Hasluck, Bektaşilik Tetkikleri, Çev. Ragıp Hulusi, Sad. Kamil Akarsu, (Ankara: Milli Eğitim Bakanlığ1 Yay., 2000), s. 51-52.

18 Öyle ki zaman içerisinde yeniçerilerin bir takım usûl ve merasimlerde Bektaşiliği taklit etmelerinden dolayı "Tâife-i Bektâşiyye" ve "Tâife-i Bektâşiyân”" gibi isimlerle adlandırıldıkları görülmektedir. Bkz. Faroqhi, Anadolu'da Bektaşilik, s. 138; ayrıca yeniçerilerle Bektaşilik arasındaki ilişki için bkz., A. Yılmaz Soyyer, 19. Yü̈ynlda Bektaşilike, (İstanbul: Frida Yay., 2012), s. 72-77; Maden, Bektaşî Tekekelerinin Kapatılması (1826), (Ankara: Türk Tarih Kurumu Yay., 2018), s. 16-26.

19 Faroqhi, Anadolu'da Bektaşilik, s. 138; ayrıca, bu noktada Faroqhi'nin "Bektaşîler ile yeniçeriler arasındaki ilişkilerin abartılmaması gerekir. İstanbul ve Kahire dışında kalan Bektaşî zaviyeleri, yeniçerilerle pek fazla bağlantı kurmuş gözükmemektedir. Mesela, 16. yüzyılda Bektaşî tarikatının yayılıp genişlemesini tamamıyla ya da büyük oranda yeniçeri ocağının desteğine bağlamak kesinlikle hatalıdır” tespiti, dikkat çekici bir tespit olup bu noktada ezber bozucu bir özelliğe sahiptir. Bkz., Faroqhi, Anadolu'da Bektaşilik, s. 188. 


\section{Balım Sultan'dan Sonra Yaşanan Gelişmeler}

Balım Sultan'ın ölümünden sonra Hacıbektaş'taki dergâhın başına kardeşi Kalender Çelebi geçmiştir. Kalender Çelebi'nin ilk dönemleri sakin geçmekle birlikte sonrası aynı şekilde geçmemiş; zira onun taraftarlarıyla beraber Baba Zünnûn ayaklanmasına iştirak etmesiyle Osmanlı tarihinin belki en geniş çaplı çiftçi-köylü ayaklanması gerçekleşmiştir. Ayrıca, bu süreçte Kalender Çelebi ile aile içinden gelen Hüdâdâd Çelebi arasında post kavgası ortaya çıkmış; Hüdâdâd Çelebi'nin Kalender Çelebi'yi öldürtmesiyle (1528) bu kavga sona ermiş; ancak ardından Kalender Çelebi'nin taraftarları da Hüdâdâd'ı öldürmüşlerdi. Bu yüzden Hacıbektaş Dergâhı, uzun yıllar post-nişînsiz kalmış; nihayet öyle anlaşılmaktadır ki devletin müdahalesiyle Balım Sultan halifelerinden olan Sersem Ali Baba, dedebaba makamının da ihdas1 üzerine, dedebaba ünvanıla 958/1551'de posta oturmuş ve bu görevi 1569 yllına kadar sürdürmüştür. ${ }^{20}$ Bundan dolayı Çelebiler ve Babagân Bektaşîleri arasındaki rekabetin yanı sıra, Çelebilerin kendi içlerinde de ailenin iki kolu arasında Mürselli-Hüdâdâdlı farklılaşmasının yaşandığ1 görülmekte olup bu noktada Mürselli ailesinin, diğerinden daha ayrıcalıklı olduğu anlaşılmaktadır. Zira Mürselliler, pir postuna oturan aile olmalarının yanında vakıfların yönetimi de ellerinde bulunuyordu. ${ }^{21} \mathrm{Bu}$ gelişmelerle birlikte Bektaşilliğin yapısındaki değişikliklerin 1650'li yıllarda artık tamamlandığı anlaşılmaktadır.

XVI. ve XVII. yüzyıllarda artık Hacı Bektaş Dergâhı, imparatorluk coğrafyasında geniş bir dergâh ve tekke ağını kontrol eder hale gelmiştir. Bu dergâh ve tekkeler içerisinde ilk anda akla gelenleri, Misır'da Kaygusuz Abdal Tekkesi, Balkanlar'da Seyyid Ali Sultan, Otman Baba, Demir Baba ve Akyazılı Sultan tekkeleri, Suriye Halep'te Bayram Baba Tekkesi, Irak'in başkenti Bağdat'ta Gürgür Baba Tekkesi ile Azerbaycan'da Pir Samit, Güneş Dede ve Postinpuş Baba tekkeleridir. ${ }^{22}$

\footnotetext{
Noyan, I, 306-307.

21 Yaman, 11; Müfid Yüksel, Bektaşilik ve Mebmed Ali Hilmî Dedebaba, (İstanbul: Bakış Yay., 2002), s. 221-222.

22 Baki Öz, Dünyada ve Türkiye'de Alevi-Bektaşi Dergâblar, (İstanbul: Can Yay., 2001), s. 305-316; Koca, 282-287.
} 
Hacı Bektaş Dergâhı, bu süreçte artık Safevîler'le ilişkileri kesilen kızılbaş ocakları ile yakınlaşmaya başlamıştı. Bu gelişmelerin sonunda özellikle Orta ve Batı Anadolu coğrafyasında yaşayan Kızılbaş-Alevî ocaklarının önemli bir kısmı, Hacı Bektaş Dergâhı'nı ve bu dergâhı temsil eden Çelebi ailesini en üst manevi otorite olarak kabul ederek onlara bağlanmışlardır. Öte yandan doğu Anadolu coğrafyasında yaşayan ocaklar ise, Hacı Bektaş Velî’nin üstünlügünü onaylayıp onu derin bir sayg1 ile anmakla birlikte Çelebi ailesine bağlanmayı kabul etmemişlerdir. ${ }^{23}$

XIX. yüzyıla gelindiğinde Anadolu'daki düzen ve huzurun bozulup bazı halk kesimlerinin devlete başkaldırmalarının sonucunda Sultan II. Mahmut, 1826 yilında Yeniçeri ocağını ortadan kaldırarak ocağın Bektaşîlik ile olan ilişkisini artık kesmiştir. Bu dönem, Bektaşiliğin tarihsel gelişiminde, her yönüyle yeni bir dönemdir. Zira Bektaşilik ve Bektaşîler açısından güçlü ve ihtişamlı dönemler artık geride kalacaktır. Bunun en önemli göstergelerinden biri, bu döneme kadar Yeniçeri ocağında miralay rütbesiyle temsil edilen Bektaşî şeyhliğine artık son verilmesidir. Bu süreçte Sultan II. Mahmut, 1827 tarihinde yayınlamış olduğu bir fermanla “Anadolu'daki bütün Bektaşî tekkelerinin, türbe mahalleri hariç, bütün binalarının yıktırılmasını, eşya, emlak ve musakkafatların istirdâdı ile devlete gelir kaydedilmesini ve Hamdullah Çelebi'nin de Amasya'ya sürgün edilmesini”' emretmişti. ${ }^{24}$

Yeniçeriliğin tasfiyesinin ardından Bektaşilik açısından ciddi bir bask1 dönemi başlamış oldu ve bu yüzden Bektaşî tekkelerinin kapatılmasına karar verildi. Bu kararın alınmasında, tahmin edileceği gibi, pek çok neden bulunmaktaydı; ancak bunların yanı sıra Bektaşîler arasında yaygın olduğu iddia edilen Râfızî inançlar da etkili görünüyordu. $\mathrm{Bu}$ çerçevede itham edildikleri hususlar arasında beş vakit namaz ve orucun terki ile ilk üç halifeye yönelik saygısız ifadeler de yer almaktaydı. Bektaşîlerin dine aykırı davrandıkları ve yeniçerilerin de bunlardan

\footnotetext{
Yıldırım, Geleneksel Alevilik, (İstanbul: İletişim Yay., 2018), s. 232-233.

24 Fiğlalı, 171; Faroqhi, Anadolu'da Bektaşilik, s. 172-173; Maden, Bektaş̂ิ Tekekelerinin Kapatılmasi, s. 74-75.
} 
etkilendiği ileri sürülüyordu. ${ }^{25} \mathrm{Bu}$ yasaklı dönemde Bektaşî çevrelere yönelik yoğun bir takibat politikası uygulanmış ve bunun sonucunda birçok Bektaşî babası, ya idam edilmiş, ya da sürgüne gönderilmiş ve bunun sonucunda Bektaşîler'den boşalan bütün mevkilere Nakşibendî şeyhleri atanmıştır. Örnek olarak Hacıbektaş Dergâhı'na post-nişîn olarak Nakşî şeyhlerinden Mehmet Said Efendi getirilmisstir. Cezalandırılan Bektaşîler arasında Şânizâde Muhammed Ataullah Efendi, Melekpaşazâde Abdülkadir Bey ve İsmail Ferruh Efendi gibi haksız biçimde bu muameleye maruz kalanlar da vardı. Bunların yanında Anadolu ve Balkanlar'da bulunan pek çok Bektaşî tekkesine de el konularak malları müsadere edildi ve Bektaşîlerin her çeşit yayını yasaklandi. ${ }^{26}$

$\mathrm{Bu}$ çalkantılı dönemde aldığı ağır darbelerden sonra Bektaşî çevreler, Anadolu dışına çıkarak, özellikle Balkanlar’a geçmişler ve merkez olarak Arnavutluk'u seçmişlerdir. Bu süreçte İstanbul ve çevresinde kalanlar ise, Melâmetîlik, Halvetîlik ve Rifâillik gibi diğer tarikatlar içinde kendilerine barınma ve tutunma imkanı aramışlardır. ${ }^{27} \mathrm{Bu}$ gelişmelerden daha çok şehir merkezlerinde yaşayan Babagân Bektaşîleri etkilenmiş olup kırsal alanda köylerde yaşayan Alevî çevreler, zaten devletin etki ve nüfuz alanı dışında bulunduklarından dolayı onlar için değişen pek bir şey olmamıştır.

Öyle anlaşılmaktadır ki Bektaşilik, bu çalkantılı süreçte Sünnî tarikatlar çerçevesinde Sünnîlik içerisinde eritilmek istenmiştir. Ancak Osmanlı merkezî yönetiminin bu yöndeki çaba ve uygulamalarının beklenilen sonucu vermediği de görülmektedir. Zira Bektaşî çevrelerin yasakçı politika ve propagandalara yönelik vermiş olduğu ilk tepkiler, yasaklılığın getirdiği travmayı atlatmak amacıyla, öncelikle içe kapanmak ve karş1 tedbirler almak şeklinde ortaya çıktı. Örnek olarak ilk etapta kılık-kıyafet değişikliği gerçekleştirildi. Yine Bektaşî çevreler, yoğun

25 Es'ad Efendi, Üss-i Zafer, Haz. Mehmet Arslan, (İstanbul: Kitabevi Yay., 2005), s. 168-169; Faroqhi, Anadolu'da Bektaşilik, s. 157; Soyyer, 67-70.

26 Zekeriya Iş1k, Şeybler ve Şablar Osmanl Toplumunda Devlet-Tarikat Ilişkilerinin Gelişim ve Değişim Süręleri, (Konya: Çizgi Kitabevi Yay., 2015), s. 208-217; Maden, Bektaşı̂ Tek.kelerinin Kapatılması, s. 113-143.

27 Yaman, 112, 125. 
takibat karşısında zarar görmemek ve izlerini kaybettirmek amaciyla kendilerine Tarîk-i Nâzenin adını vermişlerdir. ${ }^{28}$

Bektaşî çevrelere yönelik uygulanan baskıcı ve sert politikalar, II. Mahmut döneminin sonlarına doğru yavaş yavaş yumuşamış ve bu noktada ilk olarak sürgüne gönderilen Bektaşî şeyhleri affedilmişti. Örnek olarak, 1839 tarihinde Halil Revnaki Baba ile Ahmed Baba tarafindan Merdivenköy'de Şahkulu Sultan Tekkesi yeniden açılmıştır. Yine 1840 tarihinde Amasya'da sürgünde bulunan Hacı Bektaş Velî tekkesi şeyhi Hamdullah Baba affedilmiş ve tekke vakfina ait gelirlerden kendisine hisse ayrilmıştır. ${ }^{29}$

II. Mahmut döneminin sonlarında başlayan bu yumuşama süreci, oğlu Sultan I. Abdülmecid döneminde (1839-1861) devam etmiş ve özellikle Sultan Abdülaziz döneminde Bektaşî tekkelerinin yeniden açılmasıyla birlikte artık yeni bir dönem başlamıştır. Böylece bu dönemde tarikatın önü yeniden açılmış, Bektaşî çevreler toparlanma çabası içine girmişler ve artık gizlenmeye gerek duymadan faaliyetlerini açıktan yürütmeye başlamışlardır. Bu süreçte Bektaşî şeyhleriyle devlet arasında gerçekleşen resmi yazışmaların yanında Bektaşîlik’le ilgili yayınlarda dikkate değer bir artışın görülmesi, bunu teyit etmektedir. ${ }^{30}$ Böylece Sultan Abdülaziz döneminde Bektaşî çevrelerin, II. Mahmut öncesinde olduğu gibi, tekrar serbest bir ortama kavuştukları görülmektedir.

II. Abdülhamid'in sultan olmasiyla birlikte Bektaşî çevrelere yönelik yeniden ciddi engellemeler ortaya çıtı ve bu dönemde Bektaşîlerin bazı yayınları yasaklanarak toplattırıldı. Bunlardan biri, Ahmed Rufat Efendi'nin Harputlu Hoca İshak Efendi'ye Bektaşiliği savunmak amaciyla reddiye mahiyetinde yazmiş olduğu Mir'âtü'l-Mekâsıd fì Defi'l-Mefâsid (İst., 1293/1876) isimli eserdi. Bu dönemde ilginç

28 Maden, Hacı Bektas-ı Veli, s. 84

29 Maden, Hacı Bektaş-ı Veli, s. 85-86.

30 Soyyer, 81-84; Maden, Bektaşî Tekekelerinin Kapatılması, s. 207-295; Muharrem Varol, Islahat Siyaset Tarikat Bektasiliğin İlgası Sonrasinda Osmanl Devletinin Tarikat Politikalar (1826-1866), (İstanbul: Dergâh Yay, 2013), s. 61-80. 
biçimde, özellikle Babagân kolu, II. Abdülhamid ile kayda değer bir yakınlık tesis etmişti. ${ }^{31}$

II. Meșrutiyet döneminde Bektaşî çevreler arasında yeniden bir canlanma görülmüştür. Bu dönemde Ahmed Rıfk1 Baba'nın Bektaşı̂ Sırr isimli eseri yazmas1 (1909), yine periyodik bir yayın olan Mubibbân Dergisi’nin çıkması, Bektaşilik adına oldukça önemli gelişmelerdi. Bu süreçte yine bazı Bektaşîler, hem Jön Türkler hem de Yeni Osmanlılar'la birlikte hareket ederek bürokrasi ve devlet kademelerinde kendilerine yer bulmuşlardır. Tanınmış siyasetçi ve yazarlar arasında da taraftar bulan Bektaşî çevreler, Osmanlı'nın son dönemlerinde mason örgütlenmeleriyle de ilişki kurmuşlardır. ${ }^{32}$ Artık Bektaşî tekkeleri, yeniden açılarak canlı hale gelmiş ve Bektaşî çevreleri devlete küskünlüklerini sürdürmekle birlikte, kısmen Melâmetîlik şemsiyesi altında olsa da, bir silkinme ve canlanma içine girmişlerdir.

Bu canlilık süreci, daha sonra hem Birinci Dünya Savaşı, hem de Kurtuluş Savaşı'nda devam etmiştir. Birinci Dünya Savaşı sırasında Hacıbektaş Dergâhı'nın başında bulunan Ahmed Cemaleddin Çelebi, Bektaşî çevrelerden oluşturduğu "Mücâhidîn-i Bektâssisyye" isimli gönüllü bir birlikle doğu cephesinde savaşa katılmıştır. Kurtuluş Savaşı cereyan ederken yine Ahmed Cemaleddin Çelebi ile Hacıbektaş'ta Babagân kolunun post-nişîni olan Salih Niyazi Dedebaba, Atatürk'le sık1 bir işbirliği içine girerek milli mücadeleyi aktif biçimde desteklemiştir. Anadolu'daki bütün çevreler gibi Alevî-Bektaşî kesimler de kurtuluş mücadelesine canla başla katılmışlardır. ${ }^{33}$

Cumhuriyet'in ilanından sonraki süreçte artık yeni bir dönem başlamış ve bu yeni dönemde 30 Kasım 1925 tarihinde çıkarılan 677 sayılı kanunla dergâh, tekke ve zaviyelerin kapatılmasıyla birlikte postnişîn Salih Niyazi Dedebaba, duymuş olduğu üzüntüyü dile getirerek 17

31 Yalçın Çakmak, Sultamın Kı̨ৃlbaşlar II. Abdülhamid Dönemi Alevi Algıs ve Siyaseti, (İstanbul: İletişim Yay., 2019), s. 101-194.

32 Ernest Ramsaur, "The Bektashi Dervishes and the Young Turks", Moslem World, (1942), s. 7-14.

33 Fiğlalı, 172-173; Y. Nuri Öztürk, Tarihi Boyunca Bektaşîlik, (İstanbul: Yeni Boyut Yay., 1997), s. 198-203; Yaman, 127-129; İlir Hamzaj, Sâlih Niyâzı̂̉ Dedebaba Hacı Bektaş Velî Dergâhı Son Postnişini, (İstanbul: Revak Kitabevi Yay., 2019), s. 15-17. 
Ocak 1930 tarihinde Arnavutluk'a göç etmiş ve 1941 yılında İtalyan işgalciler tarafindan öldürülünceye kadar burada yaşamıştır. ${ }^{34}$ Salih Niyazi Dedebaba'dan sonra Hacibektaş'ta Ali Naci Baykal, dedebaba olmuş; ancak Arnavutluk ve Misır'daki Bektaşîler, Baykal'ı dedebaba olarak tanımadıklarından dolayı Bektaşîler böylece post-nişinlik konusunda kendi içlerinde bölünmüşlerdir. Mısır'daki Kaygusuz Abdal Dergâhı'nın son post-nişîni olan Ahmed Sırrı Baba'nın yazışmaları ve eserlerinde kendisi ile ilgili bu sıfatı kullanması dikkate alındığında, bu gelişmenin etkileri daha iyi anlaşılır. Ayrıca, aynı dönemler Arnavutluk'taki Recep Ferdi Baba da, aynı sıfatı kullanıyordu. Türkiye'de Ali Naci Baykal'ın 1960 yılında ölümüyle beraber Bedri Noyan bu sıfatı taşımaya başlamıştır. Noyan'ın 6 Kasım 1997'deki ölümünden sonra Türkiye Bektaşîleri, dedebabalık konusunda ikiye ayrılmışlardır; bir kısmı Haydar Ercan Baba'yı İzmir'de "dedebaba" olarak kabul ederken, diğer bir kısmı ise, bunun geçersiz olduğunu ileri sürerek Mustafa Eke Baba'y1 yeni "dedebaba" olarak kabul etmektedirler. ${ }^{35}$

\section{SONUÇ}

Hacı Bektaş Velî tarafindan temelleri atılan Bektaşîlik, ondan sonra öğrencileri tarafından Hacı Bektaş düşüncesi ekseninde geliştirilmiş ve Balım Sultan döneminde kurumsallaşmıştır. Zira Bektaşilik, bir tarikat olarak Hacı Bektaş'a nispetle daha sonra kurumsal bir kimlik kazanmıştır. Bu noktada Hacı Bektaş'ın Cemal Seyyid, Hacım Sultan ve Abdal Musa gibi öğrenci ve takipçilerinin Bektaşilliğin gelişim sürecindeki yerleri göz ardı edilemez. Hacı Bektaş Velî’den sonraki ilk yöneliş ve oluşum süreci, Kalenderîlik içinde gerçekleşmiş olup Bektaşilik, daha sonra Hacı Bektaş an'aneleri etrafinda ortaya çıkarak XVI. yüzyılın başlarında kurumsallaşmıştır.

Bektaşilliğin kurumsallaşmasında Balım Sultan'ın büyük bir yerinin olduğu şüphesizdir. Zira Balım Sultan, âyin ve erkân bakımından bazı düzenleme ve yenilikler ortaya koymuş, örnek olarak Bektaşî cemlerindeki on iki post erkânı ile on iki hizmet geleneğini başlatmış,

34 Hülya Küçük, Kurtuluş Savaşı'nda Bektaşîler, (İstanbul: Kitap Yay., 2005), s. 194-195; Maden, Zümre-i Bektasizyan, (İstanbul: Roza Yay., 2017), s. 182-190.

35 Yüksel, 219; Hamzaj, 71-92. 
tarikat içinde mücerredlik şeklinde ifade edilen evlenmeme kuralını getirerek yeni bir mücerred dervişler zümresi meydana getirmiştir. Ayrıca Bektaşî tekkelerini yeniden yapılandırarak merkez tekkenin diğer tekkeler üzerindeki kontrolünü daha da artırmıştır. Balım Sultan döneminde geniş bir tekke ve dergâh ağına ulaşan Bektaşîlik, bu dönemde Anadolu'nun dışına çıkarak özellikle Balkan coğrafyası, Ege ve Akdeniz adaları ile Irak, Suriye, Mısır, Azerbaycan ve İran'da yayılma imkanına kavuşmuştur. Böylece XVI. ve XVII. yüzyıllarda Bektaşilik, Osmanlı toplum yaşamının hemen her alanında büyük bir nüfuz ve etkiye sahip olmuştur.

Hacı Bektaş Dergâhı'nda yetişen sufiler, Balım Sultan'ın ortaya koyduğu düzenlemelerden dolayı iki ana zümreye ayrilmış olup bu ayrışmada Hacı Bektaş Velî’nin evlenip evlenmediği meselesi, önemli bir yere sahiptir. Hacı Bektaş'ın takipçilerinin bir kısmı, onun mücerret yani bekar olarak vefat ettiğini ileri sürerken; diğer bir kesim ise, "Fatma Nuriye Ana" ile evlendiğini ileri sürer. İlk görüşü kabul edenler, Babagânlar olarak adlandırlırken; diğer görüşün takipçileri, Çelebiler'dir.

Bektaşiliğin bu coğrafyaya hükmeden Osmanlı siyasal iktidarıyla ilişkilerini önemli ölçüde yeniçeri ocağı belirlemiş, ocakla Bektaşillik arasındaki yakın bağlar, bu ilişkileri şekillendirmiştir. Ocağın güçlü olduğu dönemler, bundan özellikle İstanbul ve Balkanlar'da yaşayan Bektaşî çevreler de etkilenmiş ve buna paralel biçimde gelişimini sürdürmüştür. Özellikle XVI ve XVII. yüzyıllarda Bektaşî çevreler, Osmanlı sınırları içinde geniş bir dergâh ve tekke ağını kontrol eder hale gelmişlerdir. Ancak yeniçeri ocağının II. Mahmut döneminde kaldırılmasıyla birlikte Bektaşilik yasaklanmış, bu yeni dönemde Bektaşî çevrelere yönelik yoğun bir takibat politikası uygulanmış, pek çok Bektaşî tekkesi kapatılmıs ve birçok Bektaşî babası, ya idam edilmiş ya da sürgüne gönderilmiştir. II. Mahmut'tan sonraki süreçte ise bu sert politikalar terkedilerek bir yumuşama dönemine geçilmiş ve özellikle Sultan Abdülaziz’le birlikte tekrar serbest bir döneme girerek Bektaşî tekkelerinin yeniden açılmasıyla birlikte kendilerini ifade etmeye başlamışlardır.

Bektaşilik, Türk kültür ve sosyal hayatının tarihsel gelişim süreci içerisinde ortaya çıkan fikri boyutu yüksek önemli bir tasavvuf hareketidir. Bu hareket, tıpkı Mevlevîlik gibi, bir yandan fikri yönünün zenginliği, diğer yandan estetik yönünün güçlü oluşuyla toplumumuzun kültür, sanat ve gönül dünyasını derin bir şekilde etkilemeye devam etmektedir. 


\section{KAYNAKÇA}

Çakmak, Yalçın, Sultanın Kıəılbașlar II. Abdülhamid Dönemi Alevi Algısı ve Siyaseti, İstanbul: İletişim Yay., 2019.

Engin, Refik, Trakya ve Balkanlarda Bektasîilik ve Bektaşî Sürekleri, Malberg, Almanya: Alevi-Bektaşi Kültür Enstitüsü Yay., 2014.

Es'ad Efendi, Mehmed, Üss-i Zafer, Haz. Mehmet Arslan, İstanbul: Kitabevi Yay., 2005.

Faroqhi, Suraiya, Anadolu'da Bektaşilik, Çev. Nasuh Barın, İstanbul: Simurg Yay., 2003.

Faroqhi, Suraiya, "XVI-XVIII. Yüzyllarda Orta Anadolu'da Şeyh Aileleri", Yol Dergisi, 22, (2003), 75-87.

Fığlalı, E. Ruhi, Türkiye'de Alevîlike Bektâşîlike, İzmir: İzmir İlahiyat Vakfi Yay., 2006.

Gölpınarlı, Abdülbâki, Vilâyet-nâme Menâkıı-ı Hünkâr Hacı Bektâss-ı Velı̂, İstanbul: İnkılap Kitabevi, 1995.

Gündoğdu, Cengiz, Hacı Bektâss-ı Velì Ögretisi ve Takipsileri Hakkenda Metodik Yeni Bir Yaklassım, Ankara: Aktif Yay., 2007.

Hamzaj, İlir, Sâlih Niyâąî Dedebaba Hacı Bektaş Velî Dergâhı Son Postnişinin, İstanbul: Revak Kitabevi Yay., 2019.

Hasluck, Frederick W., Bektasîlike Tetkikleri, Çev. Ragıp Hulusi, Sad. Kamil Akarsu, Ankara: Milli Eğitim Bakanlığ1 Yay., 2000.

Iş1k, Zekeriya, Şeybler ve Şablar Osmanl Toplumunda Devlet-Tarikat İlişkilerinin Gelişim ve Değişim Süreçleri, Konya: Çizgi Kitabevi Yay., 2015.

İbn es-Serrâc, Muhammed b. Ali, Tuffâhu'l-Ervâh ve Miftâhu'l-İrbâh, Haz. Nejdet Gürkan, M. Necmettin Bardakçı, M. Saffet Sarıkaya, İstanbul: Kitap Yay., 2015.

Karakaşzâde Ömer Efendi, Nûru'l-Hüdâ Limen İhtedâ, Dersaâdet: Tasvîr-i Efkâr Mat., 1286.

Kiel, Machiel, "Sar1 Saltuk", Türkiye Diyanet Vakfi İslâm Ansiklopedisi, İstanbul: Türkiye Diyanet Vakfi Yay., 2009, 36/ 147-150. 
Koca, Şevki, Bektâşîlik ve Bektâşı̂ Dergâhları, İstanbul: Cem Vakfi Yay., 2005.

Köprülü, M. Fuad, “Anadolu Selçukluları Tarihi'nin Yerli Kaynakları”, Belleten, VII/25, İst., (1943), 379-522.

Köprülü, M. Fuad, "Bektaş”, İslam Ansiklopedisi, İstanbul: Milli Eğitim Bakanllğı Yay., (1979), 2/461-464.

Küçük, Hülya, Kurtuluş Savaşı'nda Bektaşîler, İstanbul: Kitap Yay., 2005.

Küçük, Murat, Bir Nefes Balkan Taribten Günümüze Makedonya ve Arnavutluk'ta Bektasilik, İstanbul: Horasan Yay., 2006.

Noyan, Bedri, Bütün Yönleriyle Bektâşîlike ve Alevîlik, Ankara: Ardıç Yay., 1998.

Maden, Fahri, Zümre-i Bektaşiyan, İstanbul: Roza Yay., 2017.

Maden, Fahri, Bektaşî Tekekelerinin Kapatılması (1826), Ankara: Türk Tarih Kurumu Yay., 2018.

Maden, Fahri, Hacı Bektaş-ı Veli, İstanbul: Erdem Yay., 2019.

Ocak, A. Yaşar, Osmanl Imparatorluğu'nda Marjinal Sûfîlik: Kalenderîler, Ankara: Türk Tarih Kurumu Yay., 1999.

Ocak, A. Yaşar, Sarı Saltık Popüler İslâm'in Balkanlar'daki Destanî Öncüsü, Ankara: Türk Tarih Kurumu Yay., 2002.

Öz, Baki, Dünyada ve Türkiye'de Alevi-Bektassi Dergâhlar, İstanbul: Can Yay., 2001.

Öztürk, Y. Nuri, Taribi Boyunca Bektaşilike, İstanbul: Yeni Boyut Yay., 1997.

Ramsaur, Ernest, "The Bektashi Dervishes and the Young Turks", Moslem World, (1942), 7-14.

Sayg1, Hakkı, Türklerin Balkeanlara Geçişi ve Alevi-Bektaşi Zümreler, İstanbul: Cem Vakfi Yay., 2013.

Soyyer, A. Yılmaz, 19. Yüzynlda Bektaşilike, İstanbul: Frida Yay., 2012.

Ulusoy, A. Celalettin, Hünkâr Hacu Bektass Velî ve Alevî-Bektaşî Yolu, Hacibektaş, 1986. 
Varol, Muharrem, Islahat Siyaset Tarikat Bektașiliğin İlgası Sonrasinda Osmanle Devleti'nin Tarikat Politikalar (1826-1866), İstanbul: Dergâh Yay., 2013.

Yaman, Ali, Alevilike \& Kı̨llbaşlık Taribi, İstanbul: Nokta Kitap, 2007.

Yıkmış, Meral Salman, Hacı Bektass Veli'nin Evlatlar "Yol"un Mürşitleri: Ulusoy Ailesi, İstanbul: İletişim Yay., 2014.

Yıldırım, Rıza, Gelenekesel Alevilik, İstanbul: İletişim Yay., 2018.

Yıldırım, Rıza, Hacı Bektaş Veliden Balım Sultan'a Bektaşiliğin Doğuşu, İstanbul: İletişim Yay., 2019.

Yıldız, Harun, "Balkan Coğrafyasında Alevîlik-Bektaşîlik: Farklı Ocak ve Sürekler", Uluslararası Geçmistsen Geleceğe Alevilike Semposyumu, Ankara: Alevî İnanç Birliği Vakfi, (2018), 325-349.

Yüksel, Müfid, Bektaşı̂like ve Mehmed Ali Hilmî Dedebaba, İstanbul: Bakış Yay., 2002. 